\title{
INFLUENCE OF THE COVID-19 PANDEMIC ON DENTAL PRACTICE: WHY MEASURES TO BE TAKEN - THE EXPERIENCE OF AN EUROPEAN UNIVERSITY HOSPITAL (PART 2)
}

\author{
Constantinus Politis ${ }^{1 a^{*}}$, Annette Schuermans ${ }^{2 b}$, Katrien Lagrou ${ }^{3 c}$, Mia Vande Putte ${ }^{4 d}$, Jean-Pierre Kruth ${ }^{5 e}$ \\ 'Department OMFS, Department Imaging and Pathology, Faculty of Medicine, Leuven University Hospitals, Leuven, Belgium \\ 2Department of Hygiene, Infection Control and Epidemiology, Faculty of Medicine, Leuven University Hospitals, Leuven, Belgium \\ ${ }^{3}$ Department of Laboratory Medicine, Faculty of Medicine, Leuven University Hospitals, Leuven, Belgium \\ ${ }^{4}$ Hospital Hygiene and Infection Control Department, Faculty of Medicine, Leuven University Hospitals, Leuven, Belgium \\ ${ }^{5}$ Wet Engineering Department, Technical Service, Faculty of Medicine, Leuven University Hospitals, Leuven, Belgium
}

aMD, DDS, MM, MHA, PhD, Full Professor \& Chairperson OMFS; e-mail: constantinus.politis@uzleuven.be; ORCIDiD: https://orcid.org/0000-0003-4772-9897 bMD, PhD, Professor; e-mail: annette.schuermans@uzleuven.be; ORCIDiD: https://orcid.org/0000-0002-0998-8241

PharmD, PhD, Full Professor KU Leuven; e-mail: katrien.lagrou@uzleuven.be; ORCIDiD: https://orcid.org/0000-0001-8668-1350

IInfection Control Practitioner, Expert of the Higher Health Council; ICP; e-mail: mia.vandeputte@uzleuven.be;

ORCIDiD: https://orcid.org/0000-0003-0556-5345

eEng, Ir; e-mail:jean.kruth@uzleuven.be; ORCIDiD: $\underline{\text { https://orcid.org/0000-0003-0362-8875 }}$

di) https://doi.org/10.25241/stomaeduj.2020.7(4).art.6

Background The COVID-19 pandemic does not leave the dental practice unattended. In Part 1 the reason why measures should be taken was explored.

Objective The objective is to review the measures that can be taken to minimize the risk of tranmission in the dental practice.

Data Sources These measures can be classified according to the guidelines of the National Institute for Occupational Safety and Health (NIOSH).

Study Selection A qualitative approach explores the applicability of these guidelines to the dental practice. Data Extraction In order to prevent aerosol transmission in the dental practice a large number of changes are needed. It concerns hygiene protocols, organizational protocols and architectural changes, none of which are backed by a legal framework.

Conclusion Until a vaccination program is introduced to counter the COVID-19 pandemic in a country, the dental society will need to take measures to prevent aerosol transmission in the dental office. The pyramid of measures according to NIOSH offers a suitable frame to classify all measures. Any legal regulatory intervention could use this framework.

\section{KEYWORDS}

COVID-19; Aerosol; SARS-2-COV; Personal Protective Equipment; Respirator.

\section{INTRODUCTION}

After the outbreak of COVID-19 in Wuhan, China, the virus spread to the rest of the world and on March 11, 2020, the COVID-19 pandemic was formalized by the World Health Organization. Part 1 of the manuscript did answer the question why a lasting influence of the COVID-19 pandemic on the general dental practice could be expected in the absence of a vaccination program. The second part tries to list all measures that could be taken (hygiene measures, organisational and architectural changes) and to provide a framework according to NIOSH pyramid which is well-known in the industry [1].

Received: September 13, 2020; Revised: September 18, 2020; Accepted: September 27, 2020; Published: September 29, 2020

*Corresponding author: Prof. Dr. Constantinus Politis, MD, DDS, MM, MHA, PhD; Full Professor \& Chairperson Oral \& Maxillofacial Surgery

Kapucijnenvoer 33B, BE-3000 Leuven, Belgium

Tel. +32 16 341780; Fax: +32 16 332437; e-mail: Constantinus.Politis@uzleuven.be

Copyright: $\odot 2020$ the Editorial Council for the Stomatology Edu Journal. 

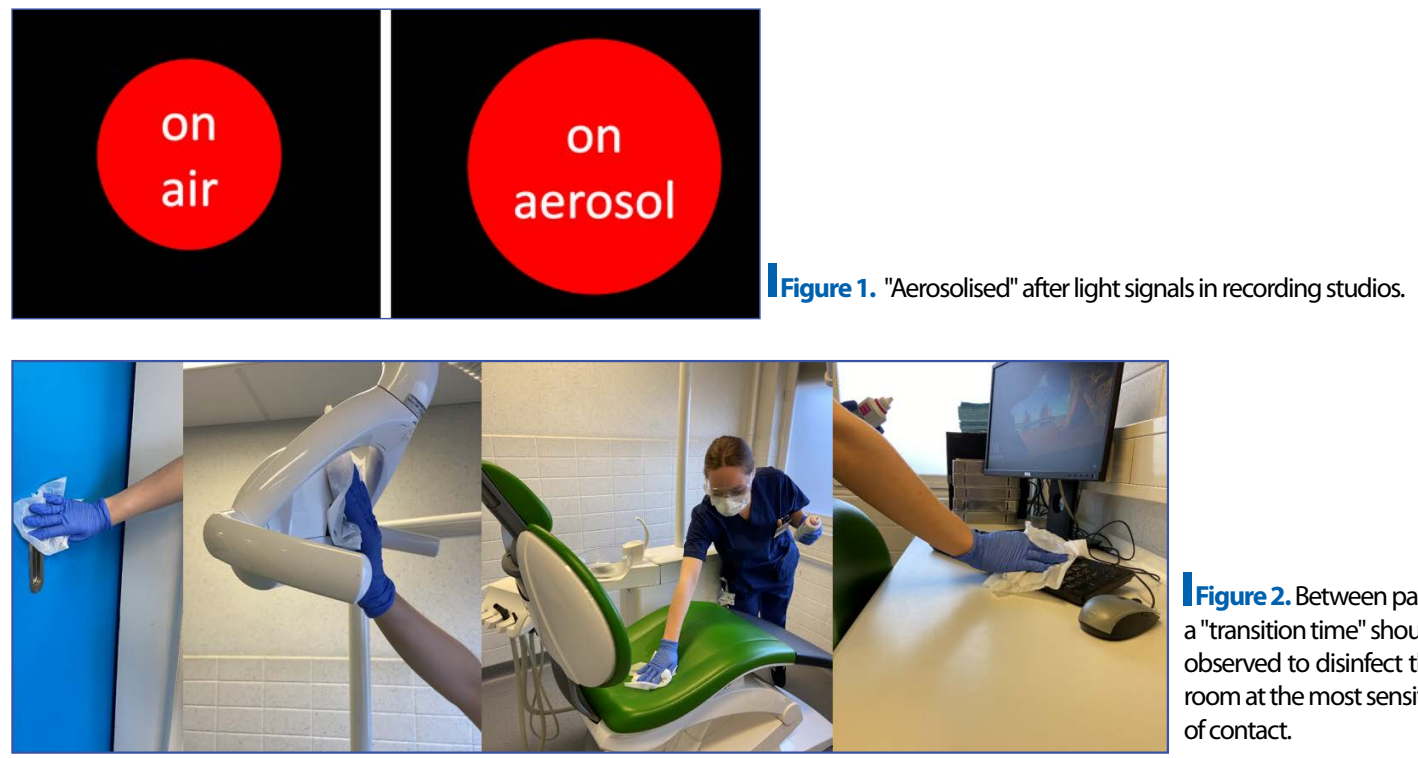

IFigure 2. Between patients, a "transition time" should be observed to disinfect the treatment room at the most sensitive points of contact.

\section{METHODOLOGY: CLASSIFICATION OF MEASURES}

When considering COVID-19 as a new infectious agent for dental practice, it seems wise to follow the pyramid of basic interventions that apply to every workplace, the "hierarchy of controls" as defined by the National Institute for Occupational Safety and Health (NIOSH) in the United States. Infection control measures can also be tested against this criterion in order to arrive at practice-oriented recommendations [2].

Five questions are asked:

- Can the agent be eliminated?

- Can the agent be replaced by a less harmful agent (substitution)?

- Can the employee be isolated from the agent (technical controls)?

-Can the working method be adapted (administrative control)?

- Is personal protective equipment (PPE) possible?

\section{RESULTS}

\subsection{Elimination}

Elimination means no exposure to the COVID-19 virus. This is the purpose of the lock-down, of the quarantine measures and PCR testing. By ensuring that, no COVID-19 positive patients in the dental practice undergo any aerosol generating procedure. Dental treatments in COVID-19 positive have been assigned to treatment centres equipped for this purpose if the treatment could not be posponed.

Another means is a vaccination schedule for the population that cancels out the virus spreading.

However, in the absence of a vaccine and systematic PCR screening, each patient must be considered as a possible source of infection for the COVID-19 virus and, mutatis mutandis, for all aerosol-transmitted germs (chicken pox, influenza, tuberculosis, measles, etc.). The elimination of the source of infection in the dental chair cannot be achieved conclusively, but in the hierarchy of measures it is preferable that it takes place as close as possible to the source, in fact as close as possible to the potentially infected patient. In concrete terms, the production and diffusion of aerosols must be tackled and contamination through direct and indirect contact with the source of contamination must be avoided or prevented.

The following measures, under the heading of elimination, will appear in infection control protocols in the future, if they are not already present :

- as soon as possible: vaccination

- questionnaires to prevent potentially infected patients coming into the dental practice

- point-of-care PCR testing

- other point-of-care diagnostic testing for COVID-19 - measuring the patient's temperature: if $>37.3^{\circ} \mathrm{C}$, the patient should contact the general practicioner.

- The patient washes his hands with soap and water and, after drying them with pure paper wipes, disinfects them with an alcohol hand solution (> $70 \%$ ) when entering the practice.

- the patient must wear a mouth mask up to the office chair

- the patient enters the practice alone (unless supervision is required)

- contactless access to the practice chair

- rinsing the mouth with $1 \%$ hydrogen peroxide or $1 \%$ povidone iodide mouthwash before any intervention causing aerosol production

- use of the rubber dam whenever possible

- use of surgical suction with a flow rate of $300 \mathrm{l} / \mathrm{min}$ where possible

- patients with drooling: scopolamine or atropine patch

- the use of mobile extra-oral fog extraction systems - the use of disinfectants in tap water of rotating instruments or ultrasonic instruments.

All current measures for cleaning and disinfecting surfaces remain valid both inside and outside the splash zone; in this case, the surface is first cleaned 


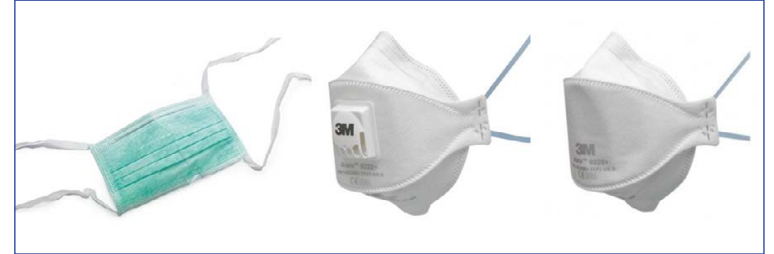

Figure 3. From left to right: a surgical nasal mask, an FFP-2 nasal mask with valve, an FFP-2 nasal mask without valve.

of visible dirt and only then disinfected following the guidelines for the correct use of disinfectant; as an example, but not exhaustively $[3,4,5,6,7,8,9,10,11,12$, $13,14,15,16]$ :

- Alcohol-free wipes (wipes) based on a mixture of several different quaternary ammonium compounds and a biguanide have a broad biocidal spectrum; this intermediate degree of disinfection is sufficient for the COVID-19 virus.

- A higher degree of disinfection can be achieved with concentrated sodium hypochlorite, but beware of chlorine applications on stainless steel: in the long term, stainless steel will be affected; especially with lower quality stainless steel, this effect will be more quickly noticeable.

- Surfaces can be disinfected with more than $70 \%$ alcohol after cleaning.

- Electrical or electronic appliances are rubbed with alcohol-based disinfectants to prevent damage. Computers, keyboards and accessories are disinfected with $70 \%$ isopropyl alcohol to prevent damage to the LCD screen.

In a hospital context, experience is gained by making the treatment room reusable during the transition period:

- Nocolysis: this involves atomisation with an $8 \%$ hydrogen peroxide solution; this hydrogen peroxide is transformed into oxygen radicals which inactivate viruses and bacteria; this mist is toxic; for a $50 \mathrm{~m}^{3}$ room, a spraying time of 3 minutes and an average waiting time of one hour (exposure time, ventilation time) is required; this solution is expensive.

- There are systems for disinfecting treatment rooms and entire operating theatres based on UV-C light, but they are not used in general dental practice because the UV-C light for this application is unprotected and toxic, but also because of the high cost of these devices [17].

The infectivity of the air depends on the size of the room, the number of air changes, the procedure (aerosol or not), the number of people in the room (coughing or not): allowing natural ventilation by opening the windows wide always has an important place in the prevention of infections $[18,19,20]$.

\subsection{Substitution}

Substitution of the infectious agent by a less harmful agent is not possible for COVID-19.

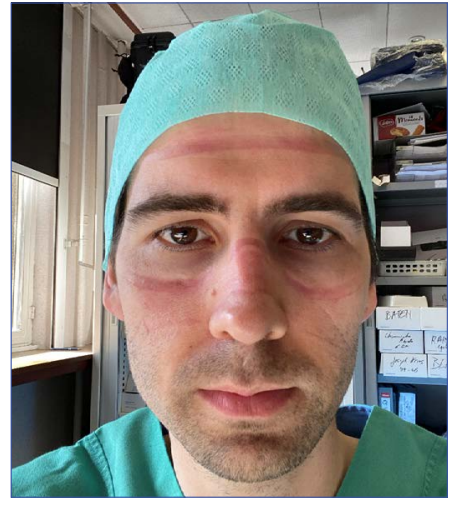

I Figure 4. Prolonged wearing of an FFP-2 mask causes pressure sores on the facial skin.

\subsection{Technical measures}

The main innovation that will be triggered by the COVID-19 virus is air treatment in dental practices. Hospitals have had to invest in this area for several decades, both for general air quality and for treatment rooms or operating theatres $[21,22,23]$.

We expect measures to be taken in both dental intervention rooms as in the general dental practice. 3.3.1.Treatment area

Hospitals have different "classes" of surgery or treatment rooms [24,25].

- A "treatment room" in a Belgian hospital has no "class", no clean or limited ventilation system, no HEPA air filtration, if possible, a ventilation rate of 6 is achieved. It is impossible to measure over- or underpressure because these treatment rooms are often not airtight. Ventilation can be achieved by opening the windows or using a ventilation device if there are no windows. Usually an ISO class 8 according to ISO14644 is obtained at rest (i.e. maximum 3520000 particles $>0.5 \mu \mathrm{m}$ and maximum 29300 particles $>5 \mu \mathrm{m}$ ). It is these particles or dusts that can serve as carriers for possible bacteria and viruses, just as aerosols can serve as carriers for the COVID virus. The number of colony-forming units allowed is $<500 \mathrm{CFU} / \mathrm{m}^{3}$. This is in fact also the situation in most dental practices.

- Class 2 operating theatres (also called performance requirement 2) have a mixed ventilation system, HEPA air filtration, a multiple ventilation factor of 6 to 30 times (criterion for new buildings). Usually an ISO class 7 according to ISO14644 is imposed at rest (i.e. max. 352000 particles $>0.5 \mu \mathrm{m}$ and max. 2930 particles $>5 \mu \mathrm{m}$ ). The permitted number of $\mathrm{CFU} / \mathrm{m}^{3}$ is $<200$. The operating theatre (zone 1 ) is normally over-pressurised compared to the rest of the hospital (zone 2) in order to protect the operating area from environmental contamination. Overpressure in the room is possible if it is constructed in a sealed manner. Different rooms can be operated by a common ventilation system. The exhaust air is always blown outside (no air recovery).

- A class 1 operating theatre (or performance requirement 1) is equipped with an unmixed ventilation system, laminar flow integrated in the plenum, HEPA filtration, a ventilation rate of between 30 and 60x per hour (criterion for new buildings), 


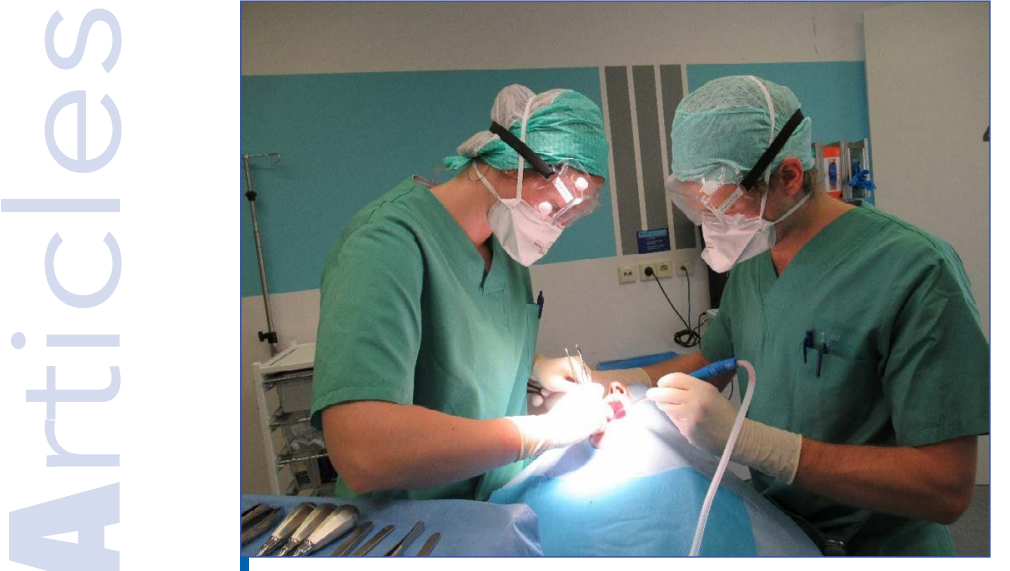

Figure 5. Procedure under local anaesthesia in a PCR negative patient with low aerosol production; no drilling. On the right, an FFP-2 mask is worn with a valve. A conventional surgical mask would have sufficed in this situation (PCR negative).

an ISO class 5 system at rest below the plenum and ISO class 7 at the periphery and a maximum of only $10 \mathrm{CFU} / \mathrm{m}^{3}$ allowed. The operating theatre (zone 1) is located in an operating room (zone 2 ) which is separated from the rest of the hospital (zone 3 ). The air flow is from zone 1 to zone 3. This type of operating theatre usually has one ventilation unit per operating theatre. The extracted air can be partially recirculated and re-injected through the HEPA- filters in the plenum.

- Fungal infections are not allowed in classrooms or treatment rooms.

- Operations under general anaesthesia usually take place in class 1 or class 2 operating theatres, while oro-maxillo-facial surgery and dental treatments which can be performed under local anaesthesia or IV sedation are located in treatment rooms.

The operating theatres operate with an overflow of air from the room to the environment to prevent pathogens from entering the operating room from outside and compromising the sterile field. This is achieved by blowing more air into the room than is sucked in. The excess air escapes from the room through the door slots or grilles. If the room is sufficiently sealed, the air flow can be properly controlled and even measured with differential pressure meters. This is called positive pressure. In the case of an infected patient in the operating room, the patient is the source of the pathogens and to maintain the source of infection in the operating room, it is necessary to modify the air flow from the environment to the operating room, or to create a negative pressure [26]. More air is then extracted than is blown in. If possible, the contaminated air is diverted to the outside by a powerful extraction system with a double filter (pre-filter and HEPA filter). If the air is recirculated anyway, as in class 1 operating rooms, it is returned through the HEPA filters into the plenum before entering the operating room again. In the dentist's treatment room, only the surgical suction is able to draw in the aerosol most powerfully

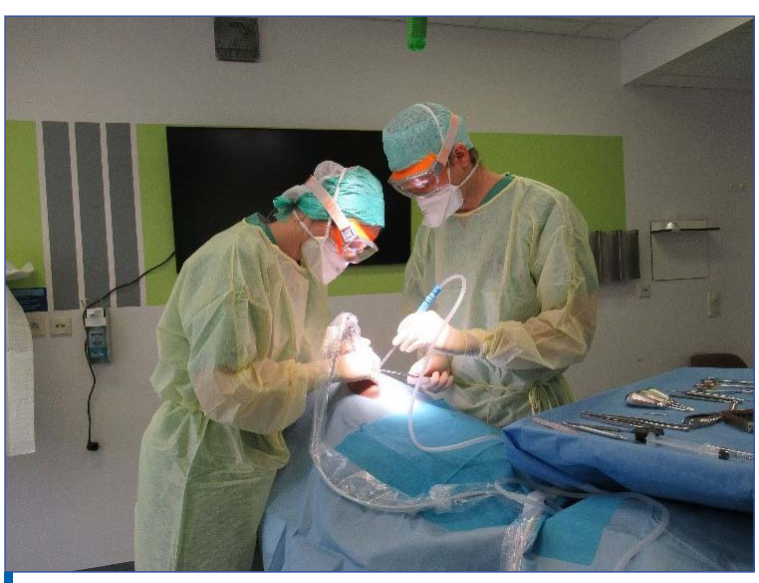

Figure 6. Procedure under local anaesthesia in a PCR-negative patient with high aerosol production; drilling takes place. In this case, it is preferable to wear safety glasses, an FFP-2 mask without a valve and a disposable apron. The FFP- 2 mask of the person on the right side of the operating table has an exhalation valve and is therefore defective.

because it is located in the aerosol production area. An ordinary saliva aspirator does little to control the production of aerosols. Surgical suction does have an effect on the transmission of droplets and droplet nuclei $[27,28]$. An extra-oral saliva aspirator may be effective in some situations, but it is designed for industrial use and is very bulky and intrusive in practice. As COVID-19 likes humidity, the installation of a dehumidifier can be defended on a theoretical basis [29]. A stand-alone dehumidifier is usually sufficient for a space of $100 \mathrm{~m}^{2}$. Humidity in a dental practice comes from the aerosols created during the dental treatments, from evaporation after disinfection of surfaces and spaces and from the autoclave. However, if regular natural (windows) or mechanical (ventilation devices) ventilation takes place, the room will already be dehumidified in this way. The added value of a stand-alone dehumidifier will then be much more limited or even non-existent. These are devices designed to purify the air quality and reduce the number of particles circulating in the air, but without any effect on the transmission of droplets :

- Air disinfection systems based on UV-C light with a peak emission wavelength of $253.7 \mathrm{~nm}$; the contaminated air is sucked into the unit where it is irradiated by a number (often 4) of UV-C lamps which inactivate all biological particles by damaging the DNA. These units can be operated during active dental treatment and do not allow UV-C radiation to escape thanks to the good shielding of the housing. There is no production of ozone or other by-products. These devices are suitable for killing bacteria, viruses and fungi. Care must be taken with UVC as UVC is harmful to plastics.

- Air disinfection systems based on HEPA filtration are realistic for the general dental practice because of the affordable price, the absence of any toxicity and because they do not require any interruption of practice. HEPA filters are well known in the hospital sector where they are integrated into the plenum of 


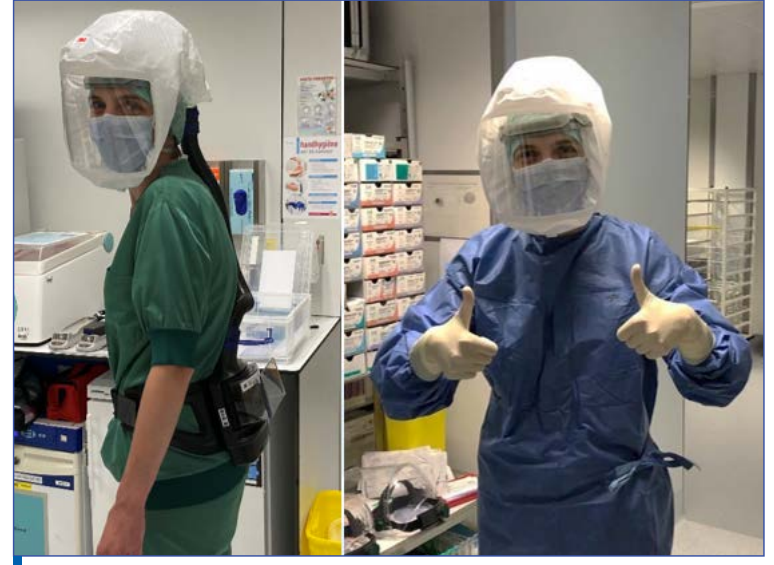

Figure 7. PPE in the form of PAPR when entering the operating room to perform an aerosol-producing procedure on a COVID-19-positive patient in the contagious phase.

operating theatres. The room air flows over a HEPA filter and an activated carbon filter with a filtration efficiency $>99.9 \%$ for all particles between $0.3 \mu \mathrm{m}$ - $0.4 \mu \mathrm{m}$. Simple commercial stand-alone units are generally suitable for treatment areas of $75 \mathrm{~m}^{3}$ and allow about 4 to 6 air changes per hour, depending on the filtration rate. The main disadvantage of these units is noise. The position of the unit must prevent aerosols from being sucked into the dentist.

- mobile or wall-mounted air purifiers based on ionisation are extremely effective and broadspectrum and are capable of removing viruses, bacteria, prions and odours [30,31,32]. The particles are, so to speak, electrocuted and collected in an activated carbon collector. In addition to pulverising the aspirated particles with negative electrons, the ioniser also creates reactive oxygen radicals. The cartridges of these air purifiers must be replaced regularly. These devices can also be installed in rooms where there is over- or underpressure. These devices have a low air flow rate. Approximately 2.5 air changes per hour are achievable for commercially accessible units. Larger units are available with more air changes per hour, but less suitable for general practice. It is important to check that the unit does not produce ozone as an end product. Most ionizers on the market are also equipped with some filters to stop coarse particles before the residue passes through the ionizer.

- Devices that inactivate micro-organisms on the basis of cold plasma (= ionised gas) and HEPAfiltration work by generating a high electric field of 10 $\mathrm{kV} / \mathrm{cm}$ in the cold plasma vacuum reactor by means of dielectric barrier discharges in which oxygen radicals disinfect the air, and the filters ensure that no particles leave the device $[33,34,35]$. These are fastacting devices (less than 2 minutes for a treatment room) with an inactivation efficiency of $>99.9 \%$ for particles greater than $0.3 \mu \mathrm{m}$ without leaving residues. The disadvantage is their weight (around $200 \mathrm{~kg}$ ) and the high cost of their maintenance. This technology was originally developed for the MIR space station. Fungi such as Aspergillus are resistant

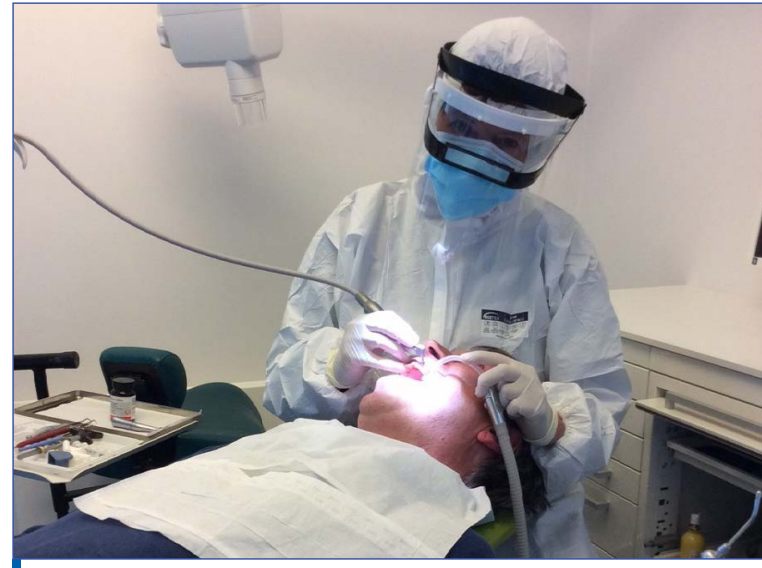

Figure 8. Even if a dentist takes maximum personal protective measures, he or she cannot prevent consecutive patients from becoming mutually infected with aerosols; additional ventilation measures are necessary.

to inactivation by cold plasma. Natural ventilation by opening windows can achieve up to 10 air changes per hour, but depends on a number of important parameters such as wind, outside temperature, window type, surface area, room orientation and opening duration of the windows. In order to reduce air contaminants by $90 \%, 2.5$ air changes are required $[36,37,38]$. The time required depends on the number of air changes per hour achieved. For the calculation of the required change time (= time needed between the last aerosol production and the entry of the next patient into the treatment room), any scientific studies carried out in a real dental practice environment are still missing. As a rough estimate, without a rocksolid scientific basis, it is assumed that the time required for 2.5 air changes with closed windows without mechanical ventilation can vary between 5 and 25 hours, whereas widely open windows on either side of the treatment room can complete the work in 5 minutes. Open windows and mechanical ventilation seem to achieve this in 15 to 30 minutes. In rooms producing aerosols, the World Health Organization does not recommend 2.5 air changes per hour, but 6 to 12. A unit with a flow rate of $400 \mathrm{~m}^{3} / \mathrm{h}$ placed in a standard $40 \mathrm{~m}^{3}$ box will provide 10 air changes per hour $[39,40]$.

3.3.2. General dental practice

In contrast to class 1 or 2 operating theatres, where the large amount of ventilation air is cooled and filtered in the ventilation system, in treatment rooms or in most dental practices, autonomous air conditioning units are required to achieve pleasant temperatures all year round. Harmful micro-organisms can escape through such systems $[41,42]$.It is therefore important to ensure that rooms, windows and doors are well sealed and to use air filters and air conditioners that are regularly maintained and replaced. In practice, filters should be replaced at least once a year and drip pans should be cleaned. For more sensitive operations, it is even recommended several times a year. Ventilation through natural or mechanical extraction works. Contamination of a dwelling adjacent to the practice by a collective ventilation 


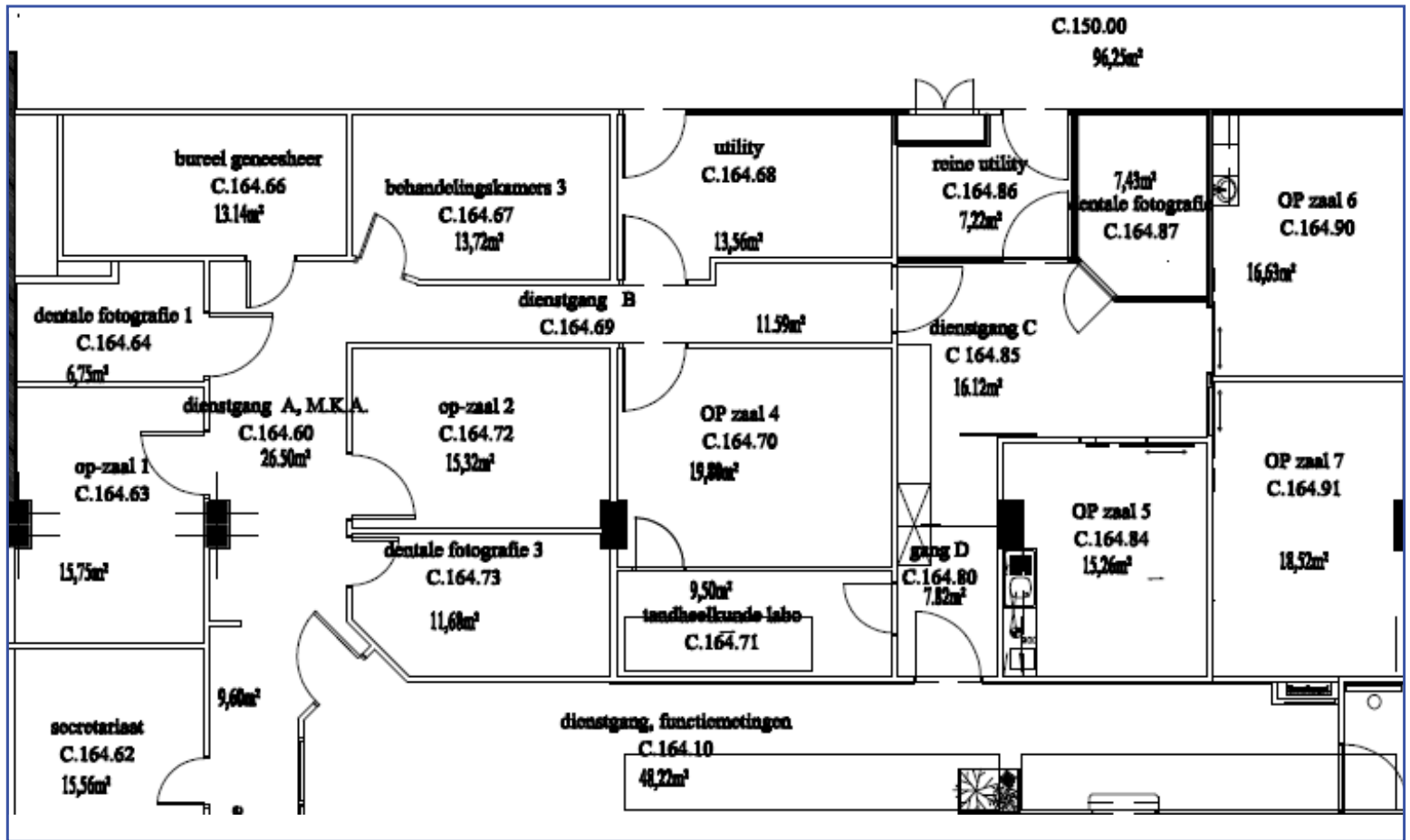

Figure 9. Most outpatient dental and oral surgery facilities are currently not equipped for aerosol control or ventilation, nor for physical separation or separate walking routes for patients and the provision of care.

system is unlikely, but it is recommended that, if possible, a distance of 5 to 10 metres should be kept between the discharge grille and open windows or the suction grille. The movement of impure air from central rooms to service rooms (garages, cellars, etc.) may be insufficient if, for example, the windows of these service rooms are open.

\subsection{Organisation of the practice}

Many trends already present in the hospital sector will accelerate their entry into the general dental practice: digital appointment management, numerous smartphone applications for contactless payment, filling in questionnaires, access and completion of one's own dental record [43].

A treatment room where an aerosol is produced will remain closed with an indicator light to prevent entry during treatment (Fig. 1). At the reception perspex creates a safe partition between the patient and the receptionist. In between two successive patients, there should be time for a complete cleaning of the unit and the contact points of the patient and the practitioner (door handle, lamp, chair, keyboard). In a conventional hospital environment, the "transition times or change-over time" in an operating theatre are known (Fig. 2) [44].

Wall posters, patient leaflets with instructions and guidelines, digital wall signs with information, signs, indicators and markings on floors and walls are among the possibilities.

In places where patients come, it should be possible to disinfect their hands and obtain a mouth mask.

The decoration of the rooms should be very sober; drinking fountains should be avoided.
Since using the toilet also causes hand disinfection by touching the glasses, the creation of an aerosol after flushing the toilet will also require technical innovations, e.g. the installation of UV-C light for decontamination, and the invitation to wash hands thoroughly after each use of the toilet should be displayed $[45,46,47,48,49]$. Pets will be left in the car park and personal belongings will remain at home or be stored in a locker. The practice is organised in such a way that contact with people and objects is kept to a minimum, including doorbells, door handles, payment terminals and other points of contact. Video consultations can be useful in general dentistry for triage, questionnaire completion, follow-up and assessment of problems that do not necessarily require an intra-oral examination.

Existing guidelines on waste management are sufficient [50]. Although less critical than not respecting deadlines in the legal profession, the expiry of storage periods for disinfectants should be monitored with the establishment of systems to record regular maintenance, cleaning, toilet cleaning. Water-based disinfectants may be stored for 7 to 14 days once opened; in the case of alcoholic solutions, no storage period is used unless limited by the manufacturer. Maintenance contracts and cost-benefit analyses and vaccination schedules for auxiliaries should not be missed.

\subsection{Personal protection measures}

As far as personal protective measures are concerned, all guidelines on hygiene and hand washing remain fully in force [51]. Nothing has changed with regard to gloves in dental practices 
either. It should be emphasised that hands must be washed or disinfected (alcohol $>70 \%$ ) before and after wearing gloves. This is because the gloves are not completely sealed. The penetration of the virus was demonstrated in $8-14 \%$ of the sterile gloves examined. Sterile gloves must also be changed every hour during critical medical procedures. The three reasons for regularly changing gloves are lack of complete occlusion, damage to the gloves by sharp objects (instruments) and contamination of the hands when removing the gloves.

Sciensano reports that it is necessary to wear professional clothing, including shoes. As aerosols can precipitate on clothing, contact contamination is possible afterwards. To avoid this, one of the following choices is recommended (Sciensano) [38]: - Wear a disposable long-sleeved apron and replace it between patients.

- Wear a long-sleeved overshirt made of washable fabric and replace it between each patient, and wash it at $60^{\circ} \mathrm{C}$ before the next use. Waterproof aprons are ideally made of polypropylene with a density of at least $25 \mathrm{~g} / \mathrm{m}^{2}$.

- Wear a washable short-sleeved fabric apron and wash the forearms between each patient.

- The aerosol-infected apron should be removed before leaving the treatment area and placed in the appropriate garbage bag or dish basket.

It makes sense to wear a surgical cap or headgear. Overshoes are not useful. Wearing professional silver-impregnated aprons makes no sense because silver usually disappears after about ten washes along with the supposed protection [52].

For patients who are known to be COVID positive and need urgent treatment, long-sleeved splash aprons and washable shoes should be worn.

The existing guidelines of the High Council of Health (Publication no. 8363) concerning the wearing of nasal masks, corrective glasses, splash goggles and face shields remain unchanged, with the difference that in addition to tuberculosis, COVID-19 can now be added [51]. The masks stop the drops that carry the virus [53,54]. An FFP-2 mask must be CE-certified and must not have an exhaust valve, as the health care provider is then protected, but not the patient (Fig. 3). Mouth masks are exorbitantly expensive in corona time: about 55 cents for a surgical mouth mask and about 10 euros for an FFP-2 mask. Theoretically, FFP3 masks offer better protection than FFP-2 masks with regard to COVID-19, but in practice FFP2 masks will suffice, also in the hospital sector. FFP stands for Filtering Facepiece Particle (filtering particle of the mask). FFP-2 is the European (EU) standard and the equivalent of the N95 nasal mask certified by the US National Institute for Occupational Safety and Health (NIOSH). An FFP mask has the disadvantage of causing pressure ulcers at pressure points and a common complaint is that it is difficult to breathe or work when worn for long periods of time (Fig. 4) [55]. In practice, this means that a dentist wears an FFP-2 mask under the surgical mask and behind the face shield or goggles during every aerosol-generating procedure, or will wear the FFP-2 mask only if he or she considers himself or herself to be one of the groups at risk of suffering from a potentially severe form of COVID-19 and therefore wishes to have additional protection during aerosol-generating treatments in the absence of PCR screening or vaccination (Fig. 5, Fig. 6). The usefulness of surgical masks and FFP-2 masks is lost if they get wet or are poorly fitted. A face shield or face mask can reduce short-term exposure to large infectious particles and thus reduce contamination of nasal mouth masks, but after 1-30 minutes, the total reduction in contamination is only $\pm 23 \%$ according to some publications [56]. Face shields are less effective against small particles. After all, these particles can stay in the air longer and can easily get behind the face mask. Nasal masks and splash goggles or face shields should not be touched by the healthcare provider in the infected area [57].

Dentists who prefer to wear a surgical mask rather than an FFP2 mask should preferably choose an FFP2 mask with a valve, which allows much more comfortable exhalation.

Reuse of surgical masks is not possible. Watering or moistening surgical mouth masks is not a good idea. FFP-2 masks can be reused twice after resterilization with hydrogen peroxide and low pressure gas sterilization [58,59]. Goggles and face shields are washed with soap and water and, after drying, disinfected with disinfectant alcohol or treated in the instrument washer. PAPRs (Powered Air-Purifying Respirators) are breathing apparatus in the form of a bonnet or full face mask with a battery-operated fan that conducts a positive air flow through a filter to the bonnet [60]. The filter is the equivalent of a HEPA filter that retains $99.7 \%$ of the particles in 0.3 $\mu \mathrm{m}$. This type of maximum protection is justified for the treatment of a COVID-positive patient in the contagious phase, but it is almost impossible to use in an ambulatory dental setting because communication with the patient is completely disrupted. There is also a high risk of infection if this PAPR is taken off (Fig. 7) [61]. Even if a dentist takes maximum personal protective measures, he cannot prevent consecutive patients from infecting each other through aerosols contaminating the air in the treatment room; additional ventilation measures are necessary (Fig. 8). An under-exposed chapter is one of the many mistakes made when putting on / taking off / removing personal protective equipment (PPE) [62]. It is almost impossible to carry out donation and removal protocols correctly without training. Wearing a beard under a mask is a common mistake. Keeping gloves on between surgeries or touching clean surfaces with soiled gloves or touching the surface of a mask with the hands explain why PPE does not figure prominently in the hierarchy of measures. 


\section{INSTRUMENTS}

With regard to dental instruments, no changes have been made to the policy described in policy document No. 8363 of the High Council of Health in 2011. The 1957 E.H. Spaulding risk categories continue to stand the test of time, even in coronary periods [63]! To grind bite plates and other tips on the chair, simply immerse them in $3 \%$ hydrogen peroxide for 30-60 seconds before sharpening.

It is also recommended not to allow unused instruments in the splash area or aerosol area to prevent contamination.

\section{ARCHITECTURAL INNOVATION}

There is no doubt that the new surgeries to be created offer great opportunities for architectural innovation, as most oral and dental surgeries are not equipped for aerosol and ventilation control (Fig. 9) [64]. Several options exist to improve ventilation,air quality and air disinfection in dental practice, apart from other architectural interventions influencing patient flows:

- The treatment cabinets could be designed to obtain negative pressure by extracting more air than it enters

- Good natural ventilation of the practice

- Air changes of at least 6 to 12 changes per hour

- Ventilation ducts that do not lead to another room where people are sitting

- Control of air inlets and outlets

- Installation of HEPA filters

- Working with several practices that allow for a time interval between practices

- Conversion of a parking space into a workspace for waiting and recharging electric cars

- Good connectivity between the practice and the car park with the necessary remote surveillance and, if necessary, automatic license plate recognition at the car park entrance or in the outside waiting area.

- The necessary facilities for maximum digitisation of the practice

- If waiting rooms are still provided, taking into account the rules of physical distance

- Concept allowing gateways with minimal contact

- Use of non-porous work surfaces and sinks impregnated with a homogeneous distribution of copper oxide (Cu-O). Copper is bactericidal and virucidal.

In dental practices, closed shelves are preferred to open shelves because open ones can be contaminated by aerosols.

Innovation will also be needed in the treatment unit to allow for quick and proper cleaning between patients:

- Swivel arms should be avoided as much as possible.

- Redesign of drill pipes, air syringe, suction for cleanability and disinfection.

- Screens must be hidden without cables

- The spit bowl should be redesigned to be extremely easy to clean and replace

- Automated pipe flushing.

It is not inconceivable that accreditation will be required in the long term for surgery rooms. This concept will have to take into account the existing ISO standards for clean rooms in order to keep pace with current regulations. ISO standards do not determine the number of air changes, but rather the maximum number of particles that can be found in the air in the room in question per cubic metre. This can be done by ventilation, filtration or both.

Again, it is possible to differentiate between orthodontic practices with many children where transmission problems (for COVID-19) have less consequences and less aerosol production compared to general dental practices where the practitioner and 28 patient are almost always connected at a short distance by an aerosol spray during intra-oral healing procedures.

\section{CONCLUSION}

The COVID-19 pandemic highlighted aerosol transmission in the chain of infection. Using the $\mathrm{NIOHS}$ pyramid of interventions a systematic approach can be utilized to combat aerosol transmission in dental practice. The development of new practices to be implemented is an excellent opportunity for architectural renewal. In addition, COVID-19 provides an impetus towards the development of new technologies that generate less aerosols and towards new concepts to facilitate the disinfection of dental facilities and practices. Extensive digitisation of the dental practice was a trend that is now becoming a necessity. Universities offer good education and training in PPE. Professional associations will be needed to maintain economically viable dental practices in the health care field, accessible to all social strata of the population.

\section{CONFLICT OF INTEREST}

The authors declare no conflict of interest.

\section{AUTHOR CONTRIBUTIONS}

All authors contributed to this paper. CP: contributed to its concept and writing. AS and MVP: contributed to the protocol. KL: contributed to the data gathering and analysis. JK: contributed to critically revising the manuscript.

\section{ACKNOWLEDGMENTS}

None. 


\section{REFERENCES}

1. Amara J. Reducing job-site risks through the hierarchy of controls [Internet]. (published Oct 16, 2019; last updated 2019-10-17; cited September 14th 2020). Available from:

https://search.proquest.com/docview/2306052949?account id $=17215$

2. Volgenant CMC, Pe rsoon IF, Ruijter RAG de, Soet JJ de. [Infection prevention in oral care during the SARS-CoV-2 outbreak.] Ned Tijdschr Tandheelkd. 2020;127(5):309-317. Dutch. doi: 10.5177/ntvt.2020.05.20031

3. von Rheinbaben $\mathrm{F}$, Wolff MH. [Manual of virus effective disinfection]. Berlin: Springer; 2002.

4. Miller $\mathrm{CH}$. Infection control and management of hazardous materials for the dental team. 5th Edition. St.Louis, MI: Elsevier; 2014. Google Scholar

5. DePaola LG, Grant LE. Infection control in the dental office. A global perspective. Cham, Switzerland: Springer; 2019.

Google Scholar

6. Volgenant CMC, De Soet JJ, Laheij AMGA. Hygiene and infection prevention in oral care practice. The Hague, Nederland: Prelum Publishers; 2018.

7. Molinari JA, Harte JA. Cottone's practical infection control in dentistry. 3rd Edition. Baltimore, MD: Wolters Kluwer-Lippincott; 2010.

8. Wood PR. Cross infection control in dentistry. London, England: Wolfe Publishing; 1992

9. McDonnell G, Sheard D. A practical guide to decontamination in healthcare. Hoboken, NJ: Wiley Blackwell; 2012.

Google Scholar

10. Pankhurst C, Coulter WA. Basic guide to infection prevention and control in dentistry. West Sussex, UK: Wiley-Blackwell; 2009. Google Scholar

11. Wattal C, Khardori N. Hospital infection prevention. Principles and practices. New Delhi, India: Springer; 2014.

12. Reybrouck G, Schuermans A, Vande Putte M. [Hygiene in Hospitals] 4th edition. Leuven, Belgium: Acco; 2000.

13. Scheurmans A. [Hygiene in Hospitals] 5th Edition. Leuven, Belgium: Acco; 2013.

14. van Ouwerkerk YM, Terpstra S. [Hygiene and infection prevention]. GA Houten, Nederland: Bohn Stafleu van Loghum; 2016.

15. Laheij A, Morsen W, de Soet $\mathrm{H}$, Volgenant C. [Infection prevention in oral practice]. DA Houten, Nederland: Prelum Uitgevers B.V.; 2017.

16. Voet DM, de Vries M. IInfection prevention from A to Z for oral care practice]. DL Houten, Nederland: Bohn Stafleu Van Loghum; 2017.

17. Yin R, Dai T, Avci $P$, et al. Light based anti-infectives: ultraviolet $C$ irradiation, photodynamic therapy, blue light, and beyond. Curr Opin Pharmacol. 2013 Oct;13(5):731-762. doi: 10.1016/j. coph.2013.08.009.

Full text links CrossRef PubMed Google Scholar Scopus WoS 18. Somsen GA, van Rijn C, Kooij S, et al. Small droplet aerosols in poorly ventilated spaces and SARS-CoV-2 transmission. Lancet Respir Med. 2020;8(7):658-659. doi:10.1016/S22132600(20)30245-9.

Full text links CrossRef PubMed Google Scholar Scopus WoS 19. Berlanga FA, Ruiz de Adana M, Olmedo I, et al. Experimental evaluation of thermal comfort, ventilation performanceindices and exposure to airborne contaminant in an airborne infectionisolation room equipped with a displacement air distribution system. Energy and Buildings. 158 (2018) 209-221. https://doi. org/10.1016/j.enbuild.2017.09.100.

Google Scholar

20. Cho J. Investigation on the contaminant distribution with improved ventilation system in hospital isolation rooms: effect of supply and exhaust air diffuser configurations. Applied Thermal Engineering. 148(2019);208-218. https://doi.org/10.1016/j.applthermaleng.2018.11.023

Google Scholar Scopus WoS

21. Andersen BM. Prevention and control of infections in hospitals. Oslo, Norway: Springer; 2019.

22. Xu Z, Zhou B. Dynamic isolation technologies in negative pressure isolation wards. Singapore: Springer; 2017 Google Scholar

23. Xu Z. Fundamentals of air cleaning technology and its application in cleanrooms. Singapore: Springer; 2014. Google Scholar

24. Belgian Superior Health Council. [Recommendations regarding infection control of the surgical wound during activities in the operating rooms] [Internet] 2013 (published May 2013; Updated 23/07/2014; cited September 14th 2020). Available from https:// www.health.belgium.be/sites/default/files/uploads/fields/ fpshealth_theme_file/19086106/Aanbevelingen\%20voor\%20 de $\% 20$ beheersing\%20van\%20de $\% 20$ postoperatieve\%20infecties\%20in\%20het\%20operatiekwartier\%20(mei\%202013)\%20 (HGR\%208573).pdf

25. DiDonna MB. Understanding what cleanroom classifications mean. [Internet] (May 2, 2017; Last Updated: 2017-05-10; Cited September 14th 2020). Available from: https://search.proquest. com/docview/1897057513?accountid=17215

26. Rebmann T. Management of patients infected with airbornespread diseases: an algorithm for infection control professionals. Am J Infect Control. 2005;33(10):571-579. doi:10.1016/j. ajic.2005.05.015

Full text links CrossRef PubMed Google Scholar Scopus WoS 27. Harrel SK, Barnes JB, Rivera-Hidalgo F. Aerosol and splatter contamination from the operative site during ultrasonic scaling. J Am Dent Assoc. 1998;129(9):1241-1249. doi:10.14219/jada. archive.1998.0421

Full text links CrossRef PubMed Google Scholar Scopus WoS 28. Harrel SK, Barnes JB, Rivera-Hidalgo F. Reduction of aerosols produced by ultrasonic scalers. J Periodontol. 1996;67(1):28-32. doi:10.1902/jop.1996.67.1.28

Full text links CrossRef PubMed Google Scholar Scopus WoS 29. Jedynakiewicz NM. A practical guide to technology in dentistry. London, UK: Wolfe Publishing; 1992.

30. Cachafeiro SP, Naveira IM, García IG. Is copper-silver ionisation safe and effective in controlling legionella?. J Hosp Infect. 2007;67(3):209-216. doi:10.1016/j.jhin.2007.07.017.

Full text links CrossRef PubMed Google Scholar

31. Skowron K, Grudlewska K, Kwiecinska-Piróg J, et al. Efficacy of radiant catalytic ionization to reduce bacterial populations in air and on different surfaces. Sci Total Environ. 2018;610-611:111120. doi:10.1016/j.scitotenv.2017.08.032.

Full text links CrossRef PubMed Google Scholar Scopus WoS

32. Escombe AR, Moore DA, Gilman RH, et al. Upper-room ultraviolet light and negative air ionization to prevent tuberculosis transmission. PLoS Med. 2009;6(3):e43. doi:10.1371/journal. pmed.1000043.

Full text links CrossRef PubMed Google Scholar Scopus WoS 33. Izadjoo M, Zack S, Kim H, Skiba J. Medical applications of cold atmospheric plasma: state of the science. J Wound Care. 2018:27(Sup9):S4-S10, doi:10.12968/jowc.2018.27.Sup9.S4. Full text links CrossRef PubMed Google Scholar Scopus WoS 34. Niedzwiedz I, Wasko A, Pawlat J, Polak-Berecka M. The State of Research on Antimicrobial Activity of Cold Plasma. Pol J Microbiol. 2019;68(2):153-164. doi:10.33073/pjm-2019-028.

Full text links CrossRef PubMed Google Scholar Scopus WoS 35. Hashim SA, Samsudin FN, Wong CS, et al. Non-therma plasma for air and water remediation. Arch Biochem Biophys. 2016;605:34-40. doi:10.1016/j.abb.2016.03.032.

Full text links PubMed Google Scholar Scopus WoS

36. Villani FA, Aiuto R, Paglia L, Re D. COVID-19 and dentistry: prevention in dental practice, a literature review. Int J Environ Res Public Health. 2020;17(12):4609. doi:10.3390/ijerph17124609.

Full text links PubMed Google Scholar Scopus WoS

37. Patini R. How to face the Post-SARS-CoV-2 outbreak era in private dental practice: current evidence for avoiding crossinfections. J Int Soc Prev Community Dent. 2020;10(3):237-239. doi:10.4103/jispcd.JISPCD 20220.

Full text links CrossRef PubMed Google Scholar Scopus WoS 38. Sciensano. [Control of SARS-CoV-2 infections in dental practices] [Internet] (Published: May 20th 202; cited: September 14th 2020).

Available from: https://covid-19.sciensano.be/sites/default/files/ Covid19/COVID19_procedure_dentists_NL.pdf

39. CDC. Guidelines for environmental infection control in healthcare facilities.[Internet] 2003 (2003; updated July 2019; cited: September 14th 2020). Available from: https://www.cdc.gov/ infectioncontrol/guidelines/environmental/index.html 40. WHO. Natural ventilation for infection control in health-care settings. [Internet] 2009 (2009; cited September 14th 2020). Available from: https://apps.who.int/iris/bitstream/handle/10665/44167/9789241547857_eng.pdf;jsessionid=A0F01390 E4A818F9D7A7F61EBAEC483D? sequence $=1$

41. Zemouri $C$, de Soet $H$, Crielaard W, Laheij A. A scoping review on bio-aerosols in healthcare and the dental environment. PLoS One. 2017;12(5):e0178007. doi:10.1371/journal.pone.0178007. Full text links CrossRef PubMed Google Scholar Scopus WoS 42. Chirico F, Sacco A, Bragazzi NL, Magnavita N. Can airconditioning systems contribute to the spread of SARS/MERS/ COVID-19 infection? Insights from a rapid review of the literature. Int J Environ Res Public Health. 2020;17(17):E6052. doi:10.3390/ ijerph17176052.

Full text links CrossRef PubMed Google Scholar Scopus 
43. Rekow D. Digital dentistry. Surrey, UK: Quintessence Publishing; 2018.

44. Mizumoto R, Cristaudo AT, Hendahewa R. A surgeon-led model to improve operating theatre change-over time and overall efficiency: a randomised controlled trial. Int J Surg. 2016;30:83-89. doi:10.1016/j.ijsu.2016.04.033

Full text links CrossRef PubMed Google Scholar Scopus WoS 45. Lai ACK, Nunayon SS, Tan TF, Li WS. A pilot study on the disinfection efficacy of localized UV on the flushing-generated spread of pathogens. J Hazard Mater. 2018;358:389-396. doi:10.1016/j. jhazmat.2018.07.003.

Full text links CrossRef PubMed Google Scholar Scopus WoS 46. Zakaria F, Harelimana B, Curko J, et al. Effectiveness of UV-C light irradiation on disinfection of an eSOS $\left({ }^{\circledR}\right)$ smart toilet evaluated in a temporary settlement in the Philippines. Int J Environ Health Res. 2016;26(5-6):536-553. doi:10.1080/09603123.2016.1 217313.

Full text links CrossRef PubMed Google Scholar

47. Johnson DL, Mead KR, Lynch RA, Hirst DV. Lifting the lid on toilet plume aerosol: a literature review with suggestions for future research. Am J Infect Control. 2013;41(3):254-258. doi:10.1016/j.ajic.2012.04.330

Full text links CrossRef PubMed Google Scholar Scopus WoS 48. Barker J, Jones MV. The potential spread of infection caused by aerosol contamination of surfaces after flushing a domestic toilet. J Appl Microbiol. 2005;99(2):339-347. doi:10.1111/j.13652672.2005.02610.x

Full text links CrossRef PubMed Google Scholar Scopus

49. Verani M, Bigazzi R, Carducci A. Viral contamination of aerosol and surfaces through toilet use in health care and other settings. Am J Infect Control. 2014;42(7):758-762. doi:10.1016/j. ajic.2014.03.026.

Full text links CrossRef PubMed Google Scholar Scopus WoS 50. Chartier Y, Emmanuel J, Pieper U, et al. Safe management of wastes from health-care activities. 2nd edition. Malta: WHO Press; 2014.

51. Superior Belgian Health Council. Recommendations for infec tion control in dental care. (May 2011; report $n^{\circ} \mathrm{CSS} 8363$ ). [Internet]. (2011; cited September 12th, 2020). Available from: https:// www.health.belgium.be/sites/default/files/uploads/fields/ fpshealth_theme_file/19069789/Aanbevelingen\%20met\%20 betrekking\%20tot\%20de\%20infectiebeheersing\%20bij\%20tandheelkundige\%20zorgverlening\%20\%28mei\%202011\%29\%20 \%28HGR\%208363\%29.pdf

52.Perelshtein I, Applerot G, Perkas N, et al. Sonochemical coating of silver nanoparticles on textile fabrics (nylon, polyester and cotton) and their antibacterial activity. Nanotechnology. 2008;19(24):245705. doi:10.1088/0957-4484/19/24/245705. Full text links CrossRef PubMed Google Scholar Scopus WoS 53. Zuo Z, Kuehn TH, Pui DY. Performance evaluation of filtering facepiece respirators using virus aerosols. Am J Infect Control. 2013;41(1):80-82. doi:10.1016/j.ajic.2012.01.010.

Full text links CrossRef PubMed Google Scholar Scopus WoS 54. Arellano-Cotrina JJ, Marengo-Coronel N, Atoche-Socola KJ, et al. Effectiveness and Recommendations for the use of dental masks in the prevention of COVID-19: a literature review [published online ahead of print, 2020 Jul 17]. Disaster Med Public Health Prep. 2020;1-6. doi:10.1017/dmp.2020.255.

Full text links CrossRef PubMed Google Scholar Scopus

55. Farronato $M$, Boccalari E, Del Rosso E, et al. A scoping review of respirator literature and a survey among dental professionals. Int J Environ Res Public Health. 2020;17(16):E5968. doi:10.3390/ ijerph17165968.

Full text links CrossRef PubMed Google Scholar Scopus WoS 56. Lindsley WG, Noti JD, Blachere FM, et al. Efficacy of face shields against cough aerosol droplets from a cough simulator. $J$ Occup Environ Hyg. 2014;11(8):509-518. doi:10.1080/15459624.2 013.877591.

Full text links CrossRef PubMed Google Scholar Scopus WoS 57. Ye G, Lin H, Chen $\mathrm{S}$, et al. Environmental contamination of SARS-CoV-2 in healthcare premises. J Infect. 2020;81(2):e1-e5. doi:10.1016/j.jinf.2020.04.034.

Full text links CrossRef PubMed Google Scholar Scopus WoS 58. Widmer AF, Richner G. Proposal for a EN 149 acceptable reprocessing method for FFP2 respirators in times of severe shortage. Antimicrob Resist Infect Control. 2020;9(1):88. doi:10.1186/ s13756-020-00744-3.

Full text links CrossRef PubMed Google Scholar Scopus WoS 59. Rubio-Romero JC, Pardo-Ferreira MDC, Torrecilla-García JA Calero-Castro S. Disposable masks: disinfection and sterilization for reuse, and non-certified manufacturing, in the face of shortages during the COVID-19 pandemic. Saf Sci. 2020;129:104830. doi:10.1016/j.ssci.2020.104830

Full text links CrossRef PubMed Google Scholar Scopus WoS 60. Dalli J, O'Keeffe DA, Khan F, Traynor O, Cahill RA. Powered Air Purifying Respirators (PAPR) for the protection of surgeons during operative tasks: a user perspective assessment [published online ahead of print, 2020 Jul 16]. Br J Surg. 2020;107(9):e328 e330. doi:10.1002/bjs.11782.

Full text links CrossRef PubMed Google Scholar

61. Licina A, Silvers A, Stuart RL. Use of powered air-purifying respirator (PAPR) by healthcare workers for preventing highly infectious viral diseases-a systematic review of evidence. Syst Rev. 2020;9(1):173 doi:10.1186/s13643-020-01431-5.

Full text links CrossRef PubMed Google Scholar WoS 62. Krein SL, Mayer J, Harrod M, et al. Identification and characterization of failures in infectious agent transmission precaution practices in hospitals: a qualitative study. JAMA Intern Med. 2018;178(8):1016-1057. doi:10.1001/jamainternmed.2018.1898 Full text links CrossRef PubMed Google Scholar Scopus WoS 63. Rutala WA, Weber DJ. Disinfection, sterilization, and antisepsis: an overview. Am J Infect Control. 2019;47S:A3-A9. doi:10.1016/j.ajic.2019.01.018

Full text links PubMed Google Scholar Scopus WoS 64. Malkin J. Medical and dental space planning. 4th Edition. Hoboken, New Jersey: Wiley; 2014.

Google Scholar

\section{Constantinus POLITIS \\ MD, DDS, MM, MHA, PhD \\ Full Professor \& Chairperson \\ Oral and Maxillofacial Surgery Department Faculty of Medicine \\ University Hospitals Leuven, KU Leuven

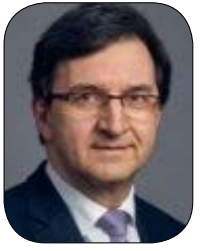

Leuven, Belgium

Dr. Politis is an Oral and Maxillo-Facial Surgeon. He is currently a Full Professor and Chairperson of the Department of OMFS at Leuven University Belgium. He is an invited Lecturer at EHSAL in Brussels. He graduated from the Catholic University of Leuven in medicine (MD) and dentistry (DDS), also specializing in oral and maxillofacial surgery at the same university. He defended his doctor's thesis on the subject of complications of orthognathic surgery (PhD). He followed additional postgraduate training in Arnhem (Stoelinga), Aachen (Koberg), Copenhagen (Pindborg), Göteborg (Bränemark) and San Francisco (Marx). He also holds a master degree in management (MM) and a master degree in Hospital Management (MHM). He is Secretary General of the Professional Union of Belgian Oral and Maxillofacial Surgeons. He is acknowledged trainer of OMFS trainees. Clinical research projects include prevention and repair of iatrogenic trigeminal nerve injury, transplantation of teeth and orthognathic surgery. 


\section{Ouestions}

\section{An operating room under negative pressure: which of the following is a correct statement?}

口a. Has no plenum;

b. Needs no HEPA-filtration;

口c. Is the de facto standard in hospitals with COVID-19 wards;

$\square d$. Is the standard when operating on COVID-19 patient.

\section{Which of following is not true or applicable when discussing humidity in a dental practice:}

$\square$ a. Humidity in a dental practice comes from the aerosols created during dental treatments;

b. Humidity in a dental practice comes from the autoclave;

ac. The added value of a stand-alone dehumidifier is only present if enough regular natural (windows) or mechanical (ventilation devices) ventilation takes place;

$\square d$. The added value of a stand-alone dehumidifier is limited or even non-existent if enough regular natural (windows) or mechanical (ventilation devices) ventilation takes place.

\section{Which of the following parameters does NOT fit the following statement: "Natural ventilation by opening windows can achieve up to 10 air changes per hour, but depends on a number of important parameters such as:"}

Da. Outside temperature;

Db. Circadian rhythm;

ac. Window type;

d. Surface area.

\section{PAPR (Powered Air-Purifying Respirator): which of the following statements is unjustified}

Da. Is synonymous for a FFP3 mask;

ab. Is a breathing apparatus in the form of a bonnet or full face mask with a battery-operated fan that conducts a positive air flow through a filter to the bonnet;

dc. Has a filter with the equivalent of a HEPA filter that retains $99.7 \%$ of the particles in $0.3 \mu \mathrm{m}$;

d. Carries a high risk of infection for the dentist when treating Covid-19 patients if this PAPR is taken off. 